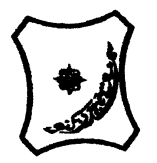

Bayero Journal of Pure and Applied Sciences, 10(1): 503 - 508

ISSN 2006 - 6996

\title{
PHYSICOCHEMICAL CHARACTERIZATION OF SOIL SAMPLE FROM SELECTED FARMS IN RIJIYAR ZAKI, UNGOGO LGA, KANO STATE
}

\author{
Abdu Muhammad Bello, ${ }^{a, *}$ and Ibrahim Rilwan Yalwa ${ }^{a}$ \\ a Department of Chemistry, School of Natural and Applied Sciences, Sa'adatu Rimi College of \\ Education Kumbotso, PMB 3218, Kano State, Nigeria \\ muhbaf70@yahoo.com
}

\begin{abstract}
Laboratory study was carried out to determine some physicochemical properties and elemental composition of soil sample from Rijiyar Zaki at Ungogo LGA of Kano state to determine its nutrient value and fertility. The elemental composition was determined using Neutron Activation Analysis (N.A.A.). After activation the sample was analyzed using a highefficiency high-purity germanium detector, the elemental concentration in the sample was determined by employing gamma spectrometry. The concentrations of $\mathrm{K}, \mathrm{Al}, \mathrm{Fe}, \mathrm{Na}, \mathrm{Ti}, \mathrm{Co}$, $\mathrm{Mn}$, and $\mathrm{Zn}$ were obtained as $1.04 \pm 0.1 \%, 5 \pm 0.1 \%, 1.2 \pm 0.06 \%, 0.0749 \pm 0.0022 \%, 0.58 \pm 0.05 \%$, $0.0004 \pm 0.00007 \%, 0.0139 \pm 0.0001 \%$, and $0.0029 \pm 0.0007 \%$, respectively, while Ca and $\mathrm{Mg}$ are below detection limit. The concentration of $A l$ in the soil sample indicates that the soil is mineral, the low $\mathrm{Na}$ content implies it is non-saline which is further confirm by the result of $\mathrm{Cl}^{-}$that indicated that the soil sample is neither saline nor purely acidic. The below detection limit obtained for Ca element may be linked to the fact that with the increase of soil $\mathrm{pH}$, soil base cations (such as $\mathrm{Ca}^{2+}$ and $\mathrm{Mg}^{2+}$ ) would precipitate with $\mathrm{OH}$, this may be the same reason for the none detection of $\mathrm{Mg}$. The study of the particle size indicated that the sample is sandy clay loam, with a silt/clay ratio of 0.83 and $\mathrm{pH}$ of 7.4. The electrical conductivity (EC), organic carbon content, cation exchange capacity (CEC), $\mathrm{PO}_{4}{ }^{3-}, \mathrm{SO}_{4}{ }^{2-}$ and $\mathrm{Cl}$ content were found to be $0.15 \mathrm{dS} / \mathrm{m}, 0.28 \mathrm{~g} / \mathrm{kg}, 8.40 \mathrm{cmol}(+) \mathrm{kg}^{-1}, 740 \mathrm{ppm}, 0.550 \mathrm{ppm}$ and $124.3 \mathrm{ppm}$, respectively. The low silt/clay ratio indicates that the soil is made up of young parent materials with low degree of weathering, while the $\mathrm{pH}$ and electrical conductivity implies that the soil is normal. The low organic carbon content can be connected with high rate of decomposition under tropical and subtropical climates. The low clay content of the soil is the reason for the low value of the CEC. The low S content may be attributed to low clay and organic matter content, as well as pH higher than 6.0 of the sample.
\end{abstract}

Keywords: Cation Exchange Capacity; Kano; Rijiyar Zaki; Soil Sampe.

\section{INTRODUCTION}

The earth is composed of various kinds of elements. In the outer layer of the earth's crust about $98 \%$ of the total crust is composed of mainly eight elements by weight: Oxygen(47\%), Silicon (28\%), Aluminum $(8 \%)$, Iron (5\%),Calcium(4\%), Potassium(3\%), Magnesium (2\%) and others form $1.41 \%$ only. The elements in the earth's crust are rarely found exclusively, but are usually combined with other elements to make various substances known as minerals (Hailu et al., 2012). Life is dependent on soil as much as it is on water and air. Nutrients required for plant development are sourced by the soil alongside microorganisms for purification of water, retention and putrefaction of organic matter. A mixture of air, minerals, water, rock, microorganisms (protozoa, bacteria, fungi and worms) and insects are vital for the wellbeing of soil. This cycle nourishes and helps keep the soil fertile (Kogo et al., 2009).

Soil has mineral and organic components, as well as physical, chemical, and biological properties. Soil plays a vital role in human existence and survival, with trace elements contained in soil directly affecting the environment and human health. An appropriate intake of essential elements is required for good health. Excess intake of some essential elements poses a health risk. There is a need to critically examine "safe" limits for trace elements within soil at an international level. Current legislation related to environmental protection and public health sets standards for human health. Environmental and food safety are increasingly attracting the attention of the public, and there is greater interest in the analysis of the elemental content of soil and agricultural products (Zaim et al., 2016). 
Special Conference Edition, November, 2017 Essential elements are fundamental for biological systems and must be available in a specific concentration range. At too high concentrations these metals lead to toxicity, while too low concentrations lead to a decrease in metabolic activity. Nonessential metals are tolerated at very low concentrations and inhibit metabolic activity at higher concentrations. As a result of numerous uses of heavy metals in several applications there is wide distribution of these metals in soil, silt, waste and waste water. The pollution of the soil by toxic metals and radionuclide arises as a result of various human activities, such as industrial activities, agricultural activities and sewage disposal. Heavy metal contamination can be a consequence of industrial activities that eliminate residues in the soil that in long term promote their accumulation. Among the metals found more frequently are $\mathrm{Cd}, \mathrm{Pb}, \mathrm{Co}, \mathrm{Cu}, \mathrm{Hg}$, $\mathrm{Ni}, \mathrm{Si}$ and $\mathrm{Zn}$. For $\mathrm{Cd}, \mathrm{Pb}, \mathrm{Cu}$ and $\mathrm{Zn}$, their toxicity increases as follows: $\mathrm{Pb}<\mathrm{Zn}<\mathrm{Cu}<\mathrm{Cd}$, depending on countless abiotic and biotic factors (Kumar et al., 2012).

Trace elements may be bound in the soil: (a) in water-soluble form, (b) as exchangeable ions, (c) as non-exchangeable elements in an organic complex (d) in association with iron, aluminium, and sometimes manganese oxide (e) as constituents of the crystal lattices of other sand-, silt-, and clay-sized minerals.

Today Neutron Activation Analysis (NAA) is widely applied in biomedical, environmental, industrial, geological and archaeological fields. Due to its sensitivity, precision and accuracy it is considered an ideal method for the determination of a large number of trace elements in several materials (Ehmann and Vance, 1991). Neutron Activation Analysis in its instrumental form (INAA), especially with research reactors, has some unique features, which makes it attractive to use for routine analysis. These are multielement capability, rapidity, reproducibility of results, complementary to other methods, freedom from analytical blank and independence of chemical state of elements (Jonah et al., 2006).

These techniques can be used in qualitative as well as in quantitative analysis. Suppose an element present in a sample is to be identified by means of neutron activation analysis, the sample will be bombarded with neutrons or other charged particles (slow neutrons are more effective). As a result of this bombardment the non-radioactive element present in the sample is converted into its radioactive isotope which will decay giving out its characteristics radiations. From half-life period measurement, it is possible to identify the element from which the radioisotope has resulted (Jonah et al., 2006).

The present study employ the application of NAA and other methods to determine the elemental composition as well as the physicochemical characteristics of soil sample obtained from Rijiyar Zaki in Ungogo LGA, Kano state. The aim of the study is to assess the fertility status of the soil sample and nutrient content. There is no available report on the fertility assessment of this soil, this prompted the present study to undertake the research, with the hope that the result obtained will serve as baseline data for the soil in this area.

\section{MATERIALS AND METHODS}

Sampling: Samples were obtained from different locations at the depth of 1 to 2 meters using plastic hand shovel. About $5 \mathrm{~kg}$ of the sample was immediately taken to laboratory in polythene bag.

Sample Treatment: The soil sample was airdried by spreading out thinly in a dry, warm and well ventilated room at room temperature. The sample was grinded using porcelain mortar and pestle and sieved through 65 mesh sieve. The sample was then sealed in polythene bag and stored for analysis. All the reagents were of analytical grade and used without further purification.

Elemental Analysis using NAA Method

Certified reference material IAEA-Soil-7 was used to determine the calibration factors for all elements, except $\mathrm{Au}, \mathrm{Cl}, \mathrm{Cu}$, and In, for which standards were prepared in-house. For irradiation, two schemes were adopted based on the half-life of product radionuclide.

For the elements leading to short-live deactivation products the samples were each packed and sealed in $7 \mathrm{~cm}^{3}$ rabbit capsules and sent for irradiation in turn in an outer irradiation channel B4, where the neutron spectrum is 'soft'. The choice of the outer irradiation channel was to eliminate corrections due to nuclear interferences caused by threshold reactions, notably $\mathrm{Mg}$ in the presence of $\mathrm{Al}, \mathrm{Al}$ in the presence of $\mathrm{Si}$, and $\mathrm{Na}$ in the presence of $P$. This is due to the proximity of the inner channels of MNS reactors to the core leading to relatively higher ratio of fast-tothermal neutrons. For elements leading to long lived activation products, samples wrapped in polyethylene films were packed in a stack inside the $7 \mathrm{~cm}^{3}$ rabbit capsule and sealed for irradiation. Samples were irradiated for 6 hours in any of the small inner irradiation channels. Following the short irradiation regime, the first round of counting was performed for $10 \mathrm{~min}$ (i.e. S1) after a waiting time of $2-15 \mathrm{~min}$. 
Special Conference Edition, November, 2017

Samples were placed on a plexi-glass sample holder designated as " $\mathrm{H} 2$ " which corresponds to source-detector geometry of $5 \mathrm{~cm}$. The second round of counting also carried out for $10 \mathrm{~min}$, following the short irradiation regime (i.e. S2) after a waiting period of 3-4 h. Samples were counted on a plexi-glass holder designated as "H1"corresponding to a source-detector geometry of $1 \mathrm{~cm}$. With respect to the long irradiation regime, the first round of counting was carried out for $30 \mathrm{~min}$, following the long irradiation (i.e. L1) using the holder ' $\mathrm{H} 1$ ' after a waiting period of 4-5 days. The second round of counting was performed for 60 min (i.e. L2) after a cooling time of 10-15 days. Samples were counted using the plexi-glass holder " $\mathrm{H} 1$ ". The choice of cooling time and sample-detector geometry was such that detector's dead time is controlled to be less than10\% (Jonah et al, 2006).

\section{RESULTS AND DISCUSSION}

\section{Elemental composition}

In soil, the 12 most common elements are; 0 , $\mathrm{Si}, \mathrm{Al}, \mathrm{Fe}, \mathrm{C}, \mathrm{Ca}, \mathrm{K}, \mathrm{Na}, \mathrm{Mg}, \mathrm{Ti}, \mathrm{N}$. S, with the most abundant elements been those that form the aluminosilicates (Alan, 1996). Table 1 portrays the elemental composition in the soil sample under analysis. Potassium is a structural element of many soil minerals (notably feldspars and micas). In addition it undergoes fixation and release phenomena associated with the clay minerals including illite which is itself a source of the element (Allen, 1974). Four soil conditions markedly affect the amount of $\mathrm{K}$ fixed: (a) the nature of the soil colloids, (b) wetting and drying, (c) freezing and thawing and (d) the presence of excess lime (Brady, 2002). According to John et al., (2006) the total soil potassium content ranges between 0.5 to $2.5 \%$ and is lower in coarse-textured soils formed from sandstone or quartzite and higher in fine-textured soils formed from rocks high in $\mathrm{K}$-bearing minerals. From Table 1 , the $\mathrm{K}$ content of the sample was found to be $1.04 \pm 0.1 \%$. The result indicates that $K$ content is within the range stated in the literature (John et al., 2006).

Aluminium is a major element in many primary and secondary soil minerals, however, only small proportion can be chemically extracted and availability is generally low except in acid soils. Hydrated Aluminium ions are important in regulating soil $\mathrm{pH}$ and the element is often associated with iron in pedsol development. The concentrations generally encountered are 1 to $15 \%$ for mineral soil, 0.05 to $0.5 \%$ for organic

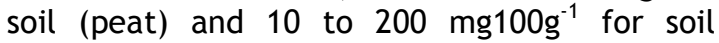
extractions (Allen, 1974). The aluminium concentration of $5 \pm 0.1 \%$ obtained in this study indicates that it can be regarded as mineral soil.

Iron comprises about $5 \%$ of the earth's crust with total iron in soil varying widely from 0.7 to $55 \%$ (John et al., 2006). From the result in Table 1, the concentration of $\mathrm{Fe}$ in the soil sample is $1.20 \pm 0.06 \%$. Although $\mathrm{Fe}$ is widely distributed in soil, deficiency can occur due to its low solubility in alkaline (calcareous) soils and also due to phosphate fixation (Allen, 1974). Although concentration of iron is low, but is still within the range.

The calcium content of soil depends on soil parent material, degree of weathering, as well as calcium addition through liming. The calcium concentration of the earth's crust is about $3.5 \%$. In acid, humid-region soils, $\mathrm{Ca}^{2+}$ and $\mathrm{Al}^{3+}$ dominate the CEC, while in neutral and calcareous soils $\mathrm{Ca}^{2+}$ occupies the majority of the exchange sites. Total $\mathrm{Ca}^{2+}$ content in soils varies widely depending on region. $\mathrm{Ca}^{2+}$ normally ranges from 0.7 to $1.5 \%$ in noncalcareous soils of humid temperate regions; however, highly weathered, tropical soils contain much lower amounts of calcium in the range of 0.1 to $0.3 \%$. Calcareous soils in semiarid regions contain 1 to $30 \% \mathrm{Ca}$, predominantly as $\mathrm{CaCO}_{3}$ (John et al., 2006). The below detection limit of $\mathrm{Ca}$ in the soil sample may be attributed to the fact that with the increase of soil $\mathrm{pH}$, soil base cations (such as $\mathrm{Ca}^{2+}$ and $\mathrm{Mg}^{2+}$ ) and available micronutrients $\left(\mathrm{Fe}^{2+}, \mathrm{Mn}^{2+}\right.$, and $\mathrm{Cu}^{2+}$ ) would precipitate with $\mathrm{OH}^{-}$(Lü et al., 2016).

Magnesium constitutes $1.93 \%$ of the earth's crust, however, total soil $\mathrm{Mg}$ content ranges from $0.1 \%$ in coarse, humid-region soils to $4 \%$ in fine-textured, arid, or semi-arid soils formed from high-magnesium minerals (John et al., 2006). According to Allen (1974), availability of magnesium is generally higher in basic and neutral soils and lower in acid where deficiency may occur. The below detection limit of $\mathrm{Mg}$ in the sample, may be attributed to the fact that much less available $\mathrm{Mg}$ exists in soils as such $\mathrm{Mg}$ deficiencies have been observed frequently (Barghouthi et al., 2012).

Sodium content in the earth's crust is about $2.8 \%$, while soils contain 0.1 to $1 \%$. Low sodium in soils indicates weathering of sodium from $\mathrm{Na}$ containing minerals. Very little exchangeable and mineral sodium occurs in humid-region soils. Sodium is most common in most arid and semi-arid region soils, where it exists as $\mathrm{NaCl}$, $\mathrm{Na}_{2} \mathrm{SO}_{4}, \mathrm{Na}_{2} \mathrm{CO}_{3}$ and $\mathrm{Na}$ salts that especially accumulates in poorly drained soils, contributing to soil salinity and sodicity (John et al., 2006). The value obtained for the soil sample of $0.0749 \pm 0.0022 \%$ in Table 1 is in correlation with the $\mathrm{pH}$ value of the soil, further confirming the soil to be non-saline. 
The most common titanium minerals are the oxides and mixed silicates. It is very widely distributed and generally high in soils, but it has no nutritional significance and little is taken up by plants. For this reason it serves as an indicator for soil contamination of plant samples. Its estimation is sometimes required in studies on soil formation. The value of $0.58 \pm 0.05 \%$ in Table 1 was an indication that the $\mathrm{Ti}$ concentration is within the range of 0.1 to $1 \%$ stated in the literature (Allen, 1974).

Total cobalt in soils typically ranges from 0.0001 to $0.007 \%$ with an average of about $0.0008 \%$. Cobalt availability decreases with greater adsorption capacity of $\mathrm{Fe} / \mathrm{Al} / \mathrm{Mn}$ oxides (John et al., 2006). The concentration of cobalt in the soil sample was found to be $0.0004 \pm 0.00007 \%$ which can be considered as low, however, within the range of 0.0001 to $0.007 \%$ stated above. The amount of cobalt in most soils is normally very low, but may increase in soils associated with basic igneous and some sedimentary rocks (Allen, 1974).

Soils have manganese concentrations that are usually in the range of 0.002 to $0.3 \%$, with an average of $0.06 \%$ (Lindsay, 1979).Manganese is present primarily as oxides and sulfides; it often occurs in association with iron. Igneous rocks have $\mathrm{Mn} / \mathrm{Fe}$ ratio of 1:60. From Table 1, the Manganese concentration of $0.0139 \pm 0.0001 \%$ of the soil sample is within the aforementioned range.

Zinc is associated with various igneous minerals, in soils it is generally held in the lattice of clay minerals and after weathering of the clay it is retained by the lattice colloids. It is freely available to plants over a wide $\mathrm{pH}$ range but less so in very acid soil. Zinc can be serious pollutant, especially in areas close to industrial plants engaged on smelting, refining and galvanizing processes (Kumar et al., 2012). Total soil zinc ranges from 0.001 to $0.03 \%$ (Lindsay, 1979). Since Zn concentration in soil is in the same range with that of the lithosphere, zinc minerals apparently do not weather more readily than average. In the present study the concentration of zinc in the soil samplewasobtainedas $0.0029 \pm 0.0007 \%$, which can be considered within the stated value above.

Table 1: Summary of Elemental Analysis

$\begin{array}{cc}\text { ELEMENT (\%) } & \text { Concentration } \\ \mathrm{Mg} & \mathrm{BDL} \\ \mathrm{Al} & 5 \pm 0.1 \\ \mathrm{Ca} & \mathrm{BDL} \\ \mathrm{Ti} & 0.58 \pm 0.05 \\ \mathrm{Mn} & 0.0139 \pm 0.0001 \\ \mathrm{Na} & 0.0749 \pm 0.0022 \\ \mathrm{~K} & 1.04 \pm 0.1 \\ \mathrm{Fe} & 1.20 \pm 0.06 \\ \mathrm{Co} & 0.0004 \pm 0.00007 \\ \mathrm{Zn} & 0.0029 \pm 0.0007\end{array}$

Physicochemical Properties of Soil Sample Table 2 summarized the physicochemical properties of the soil sample. From the particle size distribution analysis the sample is identified as sandy clay loam. In terms of the silt/clay ratio the soil sample have a value of 0.83 , it might be inferred that the sample is made up of young parent materials with low degree of weathering. Young parent materials have silt/clay ratio above 0.15 . Soils with silt/clay ratio of less than 0.25 are at an advanced stage of weathering while ratio greater than 0.25 indicated a low degree of weathering (Solarin and Ayolagba, 2006). The $\mathrm{pH}$ of the soil indicated that the sample with
pH 7.4 is neutral (Black et al., 1965). This is in agreement with the result obtained from $\mathrm{Na}$ and $\mathrm{Cl}^{-}$determination in this study that also designate the soil to be neutral.

The EC of $0.15 \mathrm{dS} / \mathrm{m}$ recorded for the soil indicates that it can be regarded as normal (i.e. not saline) (Solarin and Ayolagba, 2006). According to Agbenin, (1995) a saline soil is one with electrical conductivity exceeding $4 \mathrm{dS} / \mathrm{m}$. The OC of the soil sample was found to be $0.28 \mathrm{~g} / \mathrm{kg}$, which can be interpreted as low, since according to the literature, the range of $0.21-0.40 \mathrm{~g} / \mathrm{kg}$ is low, $0.41-0.60 \mathrm{~g} / \mathrm{kg}$ is medium, $0.61-0.80 \mathrm{~g} / \mathrm{kg}$ is medium high and $>0.80 \mathrm{~g} / \mathrm{kg}$ is high (Jaiswal, 2004). 
Special Conference Edition, November, 2017

The organic matter content varies with soils, vegetation, climate, and rotation practices, and biological activities. The content of the organic carbon is generally low because of the high rate of decomposition under tropical and subtropical climates (Shavan, 2007). The CEC value of the soil sample was found to be $8.40 \mathrm{cmol}^{(+)} \mathrm{kg}^{-1}$ which may be regarded as low. The low CEC value may be attributed to the low clay content and perhaps low organic matter. Some sandy soils or some soils of the tropics with dominant sesquioxide clays may have low CEC (Solarin and Ayolagba, 2006). This is in agreement with a literature report that stated that soil fine particles $(<0.25 \mathrm{~mm})$, especially clay, provide additional binding surfaces for exchangeable base cations and available micronutrients (Lü et al., 2016).

Colour signifies soil conditions and some important properties like availability of organic matter, colouring oxides and so on. A soil attains certain colour depending on pedochemical reactions. The colour of the sample was detected as very pale brown. This is due to different degrees of oxidation, hydration and diffusion of iron oxides in the soil, which result in red, yellow or brown colour (Shavan, 2007).

Phosphorus is very important nutrient in crop production, conversely, many soils in their natural form do not contain readily available phosphorus to improve soil fertility. The total phosphorus content of the earth's crust is about $0.12 \% . \mathrm{PO}_{4}{ }^{3-}$ in the sample under consideration was found to be 740 ppm which is within the range of $50-1500 \mathrm{ppm}$ for total $\mathrm{P}$ in surface soils reported (John et al. 2006).

The sulphur status of soil in parts per million is interpreted as follows; $0-5$ as highly deficient, 5-10 as deficient, 10-15 as marginal, 15-20 as high and 20-25 as very high (Jaiswal, 2004). From the result of $\mathrm{SO}_{4}^{-2}$ presented in Table 2, it can be infer that the sulphur status of $0.550 \mathrm{ppm}$ in the soil sample is considered as highly deficient. This may be attributed to the fact that $\mathrm{SO}_{4}{ }^{2-}$ adsorption increases with clay and organic matter(OM) content of the soil, another reason is the fact that adsorption potential of $\mathrm{SO}_{4}{ }^{2-}$ decreases with increasing $\mathrm{pH}$, and is negligible at $\mathrm{pH}>6.0$ (John et al., 2006). The low clay and organic matter (OM) content, with $\mathrm{pH}$ greater than 6.0 , may be the reason for the low adsorption of $\mathrm{SO}_{4}{ }^{2-}$, which leads to its deficiency in the soil.

Most of the Chlorine in soils is in the form of the $\mathrm{Cl}^{-}$, and leaches rather freely from humid region soils. In semi-arid and arid regions, a higher concentration might be expected, with the amount reaching the point of salt toxicity in some poorly drained saline soils. In most well-drained areas, however, one would not expect a high $\mathrm{Cl}^{-}$content in the surface of arid-region soils (Brady, 2002). Solution $\mathrm{Cl}^{-}$ranges from $0.5 \mathrm{ppm}$ in acid soils to more than $6000 \mathrm{ppm}$ in saline/sodic soils (John et al., 2006). The value of 124.3 ppm obtained in this study indicates that the sample cannot be classified as saline or purely acidic.

Table 2: Summary of Physicochemical Properties of clay Samples

\begin{tabular}{cc}
\hline Parameters & Value Obtained \\
\hline Moisture content (\%) & 0.93 \\
Colour & Very pale brown \\
$\mathrm{pH}($ in water) & 7.4 \\
$\mathrm{pH}($ in CaCl$)$ & 6.4 \\
$\mathrm{OC}$ & 0.28 \\
$\mathrm{CEC}$ & 8.40 \\
$\mathrm{EC}(\mathrm{dS} / \mathrm{m})$ & 0.15 \\
$\mathrm{Cl}^{-}(\mathrm{ppm})$ & 124.3 \\
$\mathrm{meqCO}_{3}{ }^{2-} / 100 \mathrm{~g}$ soil & 66.43 \\
$\mathrm{SO}_{4}{ }^{2-}(\mathrm{ppm})$ & 0.550 \\
$\mathrm{PO}_{4}{ }^{3-}(\mathrm{ppm})$ & 740 \\
\hline $\mathrm{OC}$ is Organic Carbon ${ }^{\mathrm{CEC}}$ is Cation Exchange Capacity, EC is Electrical Conductivity
\end{tabular}

OC is Organic Carbon, CEC is Cation Exchange Capacity, EC is Electrical Conductivity

\section{CONCLUSION}

The elemental composition as well as physicochemical properties of the soil sample determined in the present study revealed the concentrations of $\mathrm{K}, \mathrm{Al}, \mathrm{Fe}, \mathrm{Na}, \mathrm{Ti}, \mathrm{Co}, \mathrm{Mn}$ and $\mathrm{Zn}$ to be $1.04 \pm 0.1 \%, 5 \pm 0.1 \%, 1.2 \pm 0.06 \%$, $0.0749 \pm 0.0022 \%, 0.58 \pm 0.05 \%, 0.0004 \pm 0.00007 \%$, $0.0139 \pm 0.0001 \%$ and $0.0029 \pm 0.0007 \%$, respectively. The concentration of $\mathrm{Al}$ in the soil sample depicts the soil as mineral, the low $\mathrm{Na}$ content implies it is non-saline which is further confirm by the result of $\mathrm{Cl}^{-}$that indicated that the soil sample is neither saline nor purely acidic. The below detection limit obtained for Ca element may be linked to the fact that with the increase of soil $\mathrm{pH}$, soil base cations (such as $\mathrm{Ca}^{2+}$ and $\mathrm{Mg}^{2+}$ ) would precipitate with $\mathrm{OH}^{-}$, this may be the same reason for the none detection of $\mathrm{Mg}$. The study of the particle size indicated that the sample is sandy clay loam, with a silt/clay ratio of 0.83 and $\mathrm{pH}$ of 7.4 . The electrical conductivity (EC), organic carbon 
Special Conference Edition, November, 2017 content, cation exchange capacity (CEC), $\mathrm{PO}_{4}{ }^{3-}$, $\mathrm{SO}_{4}{ }^{2-}$ and $\mathrm{Cl}^{-}$content were found to be 0.15 $\mathrm{dS} / \mathrm{m}, 0.28 \mathrm{~g} / \mathrm{kg}, 8.40 \mathrm{cmol}(+) \mathrm{kg}^{-1}, 740 \mathrm{ppm}$, $0.550 \mathrm{ppm}$ and $124.3 \mathrm{ppm}$, respectively. The low silt/clay ratio indicates that the soil is made up of young parent materials with low degree of weathering, while the $\mathrm{pH}$ and electrical conductivity implied that the soil is non-saline. The low organic carbon content can be connected with high rate of decomposition under tropical and subtropical climates. The

\section{REFERENCES}

Agbenin, J. O. (1995).Laboratory Manual for Soil and Plant Analysis (selected methods and data analysis), ABU Zaria press. Pp 165.

Alan, W. (1996).Soils and the Environment. An Introduction, Cambridge University Press. P 35.

Allen, S. E. (1974).Chemical Analysis of Ecological Materials. Blackwell Scientific Publications, Oxford. Pp 119-234.

Barghouthi, Z., Amereih, S., Natsheh, B. and Salman, M. (2012). Analysis of Macro and Micronutrients in Soils from Palestine Using lon Exchange Membrane Technology. Open Journal of Soil Science, 2: 44-49.

Brady, N. C. (2002). The Nature and Properties of Soils, $10^{\text {th }}$ ed., Prentice-Hall of India Private Limited, New Delhi-11001. Pp 165358.

Ehmann, W. and Vance, D. E. (1991).Radiochemistry and Nuclear Methods of Analysis, John Wiley \& Sons, N.Y.

Hailu, A.T., Chaubey, A.K., Mamo, D.A. and Hibstie, A.Y. (2012). Application of Instrumental Neutron Activation Analysis for the Elemental Analysis of Various Rocks from Areas Around Debre Birhan City, Ethiopia. IJRRAS, 12(1):115-125.

Jaiswal, P. C. (2004). Soil, Plant and Water Analysis. Kalyani Publishers, New Delhi110 002. pp 1-247.

John, L. H., James, D. B., Samuel, L. T., and Warner, L. N. (2006). Soil Fertility and Fertilizers, An Introduction to Nutrient Management, $7^{\text {th }}$ ed., Prentice-Hall of Indian Private Limited. New Delhi-110001.

Jonah, S. A., Umar, I. M., Oladipo, M. O., Balogun, G. I. and Adeyemo, D. J. (2006).Standardization of NIRR-1 Irradiation and Counting Facilities for Instrumental Neutron Activation Analysis. Applied Radiation and Isotopes,64: 818822. low clay content of the soil is the reason for the low value of the CEC. While the low $\mathrm{SO}_{4}{ }^{2-}$ content was attributed to low clay and organic matter content, as well as $\mathrm{pH}$ higher than 6.0 of the sample. It can be inferred from the elemental composition determination that the soil sample can be considered as fertile since all the elements that are essential plant nutrients are present in the required concentration.

Kogo, B.E. Gajere, E.N. Ogunmola J.K. and Ogbole J.O. (2009). Neutron Activation Analysis of Soil Samples from Different Parts of Abuja Metropolis. Middle-East Journal of Scientific Research,4(4): 254262.

Kranskopf, K. B. (1972).Geochemistry of Micronutrients. Soil Science Society of America, Madison, WI.

Kumar, A., Joshi, V.D.,Bisht, B.S. And Srivastava, M. (2012). The solid and liquid waste of uttarakhand state carries heavy metals above permissible limit. E3 Journal of Environmental Research and Management, 3(4): 75-83.

Lindsay, W. L. (1979).Chemical Equilibria in Soils. Willey-Interscience, New York.

Lü, L., Wang, R., Liu, H., Yin, J., Xiao, J., Wang, Z., Zhao, Y., Yu, G., Han, X. and Jiang, Y. (2016).Effect of soil coarseness on soil base cations and available micronutrients in a semi-arid sandy grassland. Solid Earth, 7: 549-556.

Martin, A. (1961).Introduction to Soil Microbiology, John Wiley \& Sons, Inc. New York \& London.

Shavan, R. (2007). Handbook of Agriculture, Indian Council of Agricultural Research, New Delhi.

Shukla, G., Mishra, G. C.and Singh, S. K. (2015).Estimation of Micronutrients in the Soil. The Bioscan, 10(1): 1-4.

Solarin, L. O., and Ayolagba, G. A. (2006). Characterization and Classification of Cement Dust-Polluted Soils in Sagamu Area, Southwestern Nigeria, Nigerian Journal of Soil Science, 16: 24-34.

Stenley, A. B. (1995).Soil Nutrient Bioavailability. A Mechanistic Approach, $2^{\text {nd }}$ ed. John Wiley \& Sons, Inc. New York.

Zaim,N. Dogan,C. and Camtakan Z. (2016). Neutron Activation Analysis of Soil Samples from Different Parts of Edirne In Turkey. Journal of Applied Spectroscopy, 83(2): 271-272. 